\title{
THE ROLE OF KYAI AS A LOCAL LEADER IN THE ELECTION OF VILLAGE HEAD AT LARANGAN LUAR VILLAGE IN 2019
}

\author{
Roziq Abdul, Husein Mohammad Bustanol \\ Madura University, Indonesia \\ *E-mail: abdulrozig@unira.ac.id
}

\begin{abstract}
For Madurese community, the election of village head is not only a process of fulfilling legal requirements of formal village leadership through democratic procedures in accordance with applicable regulations, but it has broader meaning. Kyai is considered as one of the most influential informal local leader for the community that can be a role in process of forming awareness, attitudes and behavior. This research was conducted at Larangan Luar Village, Pamekasan. In collecting the data, quantitative method and likert scale were used in this research. The result of this study showed that the role of Kyai in the election of village head at Larangan Luar village in 2019 was considered moderately important.
\end{abstract}

\section{KEY WORDS}

Local Leader, Kyai, Larangan Luar Village.

Madurese people are social community with their typical character. They are popular as religious, paternalistic and toughness people. The religious character of Madurese community can be seen in their strong commitment to Islam, their socio-cultural patterns, their education, even in the residential house arrangement called Tanian Lanjang. This character is influenced by local informal leader, a Kyai, through his formal or informal institution.

Kyai as an informal local leader given by Madurese people for someone who has good understanding of Islam religion, being obedient, having good behaviour and being grown up from a Kyai family. Sometimes he complemented by supra -rational strengths that make him to be a charismatic person. On the other hand, it can weaken the critical power of community, especially those who have low educational background. Reality shows that there is a positive correlation between the level of education and the society's critical power. This means that the higher the education, the braver he will criticize his leader.

Known as social community with their typical character, the election of Village Head is not only a process of fulfilling legal requirements of formal village leadership through democratic procedures in accordance with applicable regulations, but it has broader meaning. The election of Village Head in Madura called ceplo'an, is a competition for the dignity, honor and interest of candidate, including the figures who support him. In other word, it can say that the candidate brings his and supporting figures wishes, interests and ambitions. The supporting figures usually determine certain concessions trough 'bargaining'.

Larangan Luar Village is one of fourteen villages in the Laragan District, Pamekasan Regency. Located in rural area, people have the character and the influential figures as mentioned above. From generation to generation, Larangan Luar village always lead by village head come from one family. He is not from Kyai family. Other people are reluctant to be Village Head candidate because he assumes that he will be loss.

However in the election of Village Head candidate in 2019, this assumption was not right. The winner of Village Head was from usual person. This phenomenon showed that there had been a change in the community of Larangan Luar Village. This change could be analyzed from two dimensions, namely from internal and external dimension.

Sarwoto, Gerungan and Jefta Leibo said that the most important element for a leader is when he has ability to persuade others, while A.M. Mangunhardjana stated that initiative as the crucial element for a leader. He said "a leader is a person who walks ahead, takes action 
fisrt, takes the decision, and directs the thoughts and opinion of others through his influence (Mangunhardjana, 1981, p. 11).

People take the view that Kyai as an informal leader with an extraordinary personality in a religious context. Other informal figures, including Village leader is still under the control of Kyai, even he acknowledges, respects and shows his obedience. However in certain case, such as with regard to village government affairs, competition for interest and honor, the role of Kyai also needs to be taken into account.

As a charismatic informal leader, Kyai occupies a strategic position in society. In this case, Sukamto argues that people respect the Kyai because of his good behaviour among the society.

A charismatic leader relies on the belief and view that a Kyai as informal leader is based on 'extraordinary qualities'. It is a very theological understanding because people assums that his extraordinary qualities come from God's power. The term 'charismatic' refers to the personality qualities that an individual possesses due to the superiority of his personality. He was considered and even believed that he has supernatural power. People see him as a special human being (Sukamto, 1997, pp. 40-41).

According to Mutmainnah, the role Kyai is so important in for Madurese society. It shows that a Kyai has played a polymorphic role. It is given to a type of leadership when someone with a certain status performs various roles at once (Mutmainnah, 2019, pp. 44-46).

\section{METHODS OF RESEARCH}

This research focused on the role of Kyai as a local leader in the election of village head at Larangan Luar village in 2019 by using survey method. This research was conducted for five months, from August up to December 2020.

Since this research wanted to measure the role of Kyai in the election of village head, this research was conducted at Larangan Luar village, Larangan Sub-dustrict, Pamekasan Regency.

A survey about the role of Kyai was carried out through the stages of preparation, implementation, data processing and data presentation as the following steps:

1. Developing instruments;

2. Determining Respondents;

3. Conducting research;

4. Processing the result of research;

5. Presenting and reporting the result of research.

Quantitative research that is used to describe, explain, deduce of condition, situation or phenomenon of any variables based on the reality (Sugiyono, 2011:18), Giving questionnaire to respondents was a way to get quantitative data.

The research population in this study was all the people of Larangan Luar Village who fulfill the four criteria below:

1. They had right to vote in village head election in 2019 ;

2. They used their rights in 2019;

3. They have been staying at Larangan Luar village;

4. They were able to read and write.

Because the research population was about 3944 people, it is impossible to conduct the research to all people in that village. Some samples were chosen as the research representative. The following techniques were done to choose the sample:

1. Proportional Sampling Technique;

2. Random Sampling Technique.

The questionnaire sheets were distributed by the researcher and his friends to collect some information about the role of Kyai in the election of village head (as variable $X$ ) and the role of Kyai in the implementation of village development (as variable $Y$ ). The form of the questionnaire used was a closed form. Each question item was provided with five answer options.

Documentation techniques were used to obtain demographic statistical data at the 
Larangan Luar Village Office that was related to research interests.

After the data had been collected, then it was analyzed by using Likert Scale. it was used to measure how importance the role of Kyai in the election of village head.

The five options for each questionnaire item showed the level of Kyai's role as mentioned above with the weighted scores as follows:

- Option a: score 5 means that the Kyai's role was extremely important;

- Option b: score 4 means that the Kyai's role was very important;

- Option c: score 3 means that the Kyai's role was moderately important;

- Option d: score 2 means that the Kyai's role was slightly important;

- Option e: score 1 means that the Kyai's role was not at all important.

To find out the role of Kyai in the election of village head, it was necessary to calculate the real score then to measure the five-level benchmarks, with the width of the interval (i) obtained by calculating:

$$
\mathrm{i}=\text { Range }(\mathrm{R}) / \text { Number of Intervals }
$$

Where: $R=$ (the highest score - the lowest score) +1 .

To measure the gradation of Kyai's role was carried out per questionnaire item, per indicator in one variable, per similar indicator across variables and per variable.

\section{RESULTS AND DISCUSSION}

In order to facilitate the discussion of each questionnaire item, each indicator in one variable, and each indicator across variable, it was necessary to state the real score of each questionnaire item on variable $\mathrm{X}$ as written in Table 1 below:

Table 1 - Real Score each item for Variable X

\begin{tabular}{|c|c|c|c|c|c|c|c|c|c|c|c|c|}
\hline \multirow{2}{*}{ Indicator } & \multirow{2}{*}{ No.tem } & \multicolumn{5}{|c|}{ Frequency in each option } & \multicolumn{5}{|c|}{ Frequency option $\mathrm{x}$ weight } & \multirow{2}{*}{ Total Score } \\
\hline & & a & $\mathrm{b}$ & C & $d$ & $\mathrm{e}$ & ax5 & $\mathrm{b} \times 4$ & $\mathrm{cx3}$ & $d \times 2$ & ex1 & \\
\hline \multirow{6}{*}{$\mathrm{X} 1$} & 1 & 33 & 23 & 201 & 7 & 0 & 165 & 92 & 603 & 14 & 0 & 874 \\
\hline & 2 & 156 & 21 & 58 & 26 & 3 & 780 & 84 & 174 & 52 & 3 & 1093 \\
\hline & 3 & 18 & 170 & 48 & 17 & 11 & 90 & 680 & 144 & 34 & 11 & 59 \\
\hline & 4 & 4 & 237 & 14 & 9 & 0 & 20 & 948 & 42 & 18 & 0 & 1028 \\
\hline & 5 & 88 & 11 & 146 & 8 & 11 & 440 & 44 & 438 & 16 & 11 & 949 \\
\hline & 6 & 12 & 197 & 25 & 30 & 0 & 60 & 788 & 75 & 60 & 0 & 983 \\
\hline \multirow{6}{*}{$X 2$} & 7 & 32 & 28 & 174 & 26 & 4 & 160 & 112 & 522 & 52 & 4 & 850 \\
\hline & 8 & 20 & 5 & 7 & 183 & 49 & 100 & 20 & 21 & 366 & 49 & 556 \\
\hline & 9 & 34 & 90 & 28 & 67 & 45 & 170 & 360 & 84 & 134 & 45 & 793 \\
\hline & 10 & 43 & 2 & 11 & 207 & 1 & 215 & 8 & 44 & 414 & 1 & 682 \\
\hline & 11 & 18 & 21 & 9 & 216 & 0 & 90 & 84 & 27 & 432 & 0 & 633 \\
\hline & 12 & 16 & 74 & 40 & 128 & 6 & 80 & 296 & 120 & 256 & 6 & 758 \\
\hline
\end{tabular}

The discussion of each questionnaire item was carried out by consulting the real score per item of the questionnaire against the benchmarks based on the calculation as above. The real score of each questionnaire item was the sum of the multiplication results between the weighted score and its frequency, as in table 1 and table 2 above.

The benchmark for discussion of each questionnaire item was:

- Highest Score $(\mathrm{N}) \times$ highest weight $\times$ Total item $=1320$;

- Lowest Score $(N) \times$ lowest weight $\times$ Total item = 264;

- Width of the interval is 211,2 .

It could be calculated that the width of the interval for each level as follows:

- Score > 1108 - 1320 means that the Kyai's role was extremely important;

- Score > 897 - 1108 means that the Kyai's role was very important;

- Score > 686 - 897 means that the Kyai's role was moderately important;

- Score > 475 - 686 means that the Kyai's role was slightly important;

- Score 264 - 475 means that the Kyai's role Kyai's role was not at all important.

After knowing the width of the interval for each gradation, it could be measured the level of the Kyai's role in each questionnaire item, as in the following table 
Table 2 - Gradation of the Kyai's role in every questionnaire item

\begin{tabular}{|c|c|c|}
\hline \multirow{2}{*}{ Number of Questionnaire items } & \multicolumn{2}{|c|}{ VARIABLE X } \\
\hline & Real Score & Gradation \\
\hline 1 & 2 & 3 \\
\hline 1 & 874 & $\mathrm{C}$ \\
\hline 2 & 1093 & $B$ \\
\hline 3 & 959 & $B$ \\
\hline 4 & 1028 & $B$ \\
\hline 5 & 949 & $B$ \\
\hline 1 & 2 & 3 \\
\hline 6 & 983 & $B$ \\
\hline 7 & 850 & $\mathrm{C}$ \\
\hline 8 & 556 & $\mathrm{~K}$ \\
\hline 9 & 793 & $\mathrm{C}$ \\
\hline 10 & 682 & $\mathrm{~K}$ \\
\hline 11 & 633 & $\mathrm{~K}$ \\
\hline 12 & 758 & $\mathrm{C}$ \\
\hline Total Number & 10155 & - \\
\hline
\end{tabular}

Based on Table 3, it was shown that the Kyai's role in the election of village head (variable $\mathrm{X}$ ) in each item described as follows.

Analysis of Kyai's role in the election of village head at Larangan Luar Village in terms of giving exemplary behaviour (Varibale $\mathrm{X}$, indicator $\mathrm{X} 1$ ):

- Item 1: The respondents' respond about the role of Kyai in term of his effort to ward off any deceit in the election of village head. The real score was 874 , meant that the Kyai's role was moderately important;

- Item 2: The respondents' respond about whether or not the Kyai's support was needed for one of the village head candidate. The real score was 1093, meant that the Kyai's role was very important;

- Item 3: The respondents' respond about educational and family background of village head candidate. The real score was 959, meant that the Kyai's role was very important;

- Item 4: The respondents' respond about whether or not the respondent had invited other people to support one of the candidate based on Kyai's recommendation. The real score was 1028, meant that the Kyai's role was very important;

- Item 5: The respondents' respond about the village head's basic ability without any support from the Kyai. The real score was 949, meant that the Kyai's role was very important;

- Item 6: The respondents' attitude towards the elected village head related to the Kyai's support for him. The real score was 983, meant that the Kyai's role was very important.

Analysis of Kyai's role in the election of village head at Larangan Luar Village in terms of his effort to persuade other people (variable $X$ indicator $X 2$ ):

- Item 7: The respondents' respond about whether or not he had been instructed by the Kyai to maintain peacefulness during the Village Head election process. The real score was 850 , meant that the Kyai's role was moderately important;

- Item 7: The respondents' respond about whether or not he had been instructed by the Kyai to elect certain candidate. The real score was 556, meant that the Kyai's role was slightly important;

- Item 9: The respondents' respond about the Kyai's assistant who had been instructed by the Kyai to elect certain candidate. The real score was 793, meant that the Kyai's role was moderately important;

- Item 10: The respondents' respond about whether or not he had visited the Kyai in case of village head election. The real score was 682, meant that the Kyai's role was slightly important;

- Item 11: The respondents' respond about whether or not he had been visited by the Kyai in case of village head election. The real score was 633 , meant that the Kyai's role was slightly important; 
- Item 12: The respondents' respond if he had been asked to choose the candidate based on the Kyai's instruction. The real score was 758, meant that the Kyai's role was moderately important.

The Kyai's role in each indicator could be calculated by consulting the real score for each indicator (sub-variable) against the benchmark. There were six items in each indicator that could be obtained by calculating as follow:

- Highest Score $=264 \times 5 \times 6=7920$;

- Lowest Score $=264 \times 1 \times 6=1584$;

- Width of the interval (i) $=1267$. follows:

Thus the interval number per gradation for each sub-variable could be calculated as

- Score > 6652 - 7920 means that the role of Kyai was extremely important;

- Score > 5385 - 6652 means that the role of Kyai was very important;

- Score > 4118 - 5385 means that the role of Kyai was moderately important;

- Score $>2851-4118$ means that the role of Kyai was slightly important;

- Score 1584 - 2851 means that the role of Kyai was not at all important.

While the real score in each indicator (sub-variable) was obtained by adding up the real scores of the six questionnaire items on each sub-variable. According to the data in table 1 and 2 above it can be seen that the real score for each indicator was:

- Sub-Variable (indicator) X1 indicated the Kyai's role in the election of village head at Larangan Luar village in 2019 in term of giving exemplary behavior, attitudes and thinking. The real score of this indicator was 5883. It categorized that the Kyai's role was very important;

- Sub-Variable (indicator) X2 indicated the Kyai's role in the election of village head at Larangan Luar village in 2019 in term of persuading other people. The real score of this indicator was 4272. It categorized that the Kyai's role was moderately important.

Measuring the role of Kyai in the election of village head (variable $X$ ) could be gotten by consulting the real score for each variable against the benchmark obtained by calculating as follow:

- Highest Score $=264 \times 5 \times 12=7920$;

- Lowest Score $=264 \times 1 \times 12=1584$;

- Width of the interval (i) $=2534,6$.

Since the width of the interval (i) per variable was as same as the interval scale in measurement number 3 above, the gradation of Kyai's role in each variable could use the standard used in measurement number 3 as mentioned above.

By referring to table 2 above, it could be measured the gradation of Kyai's role for variable $X$. The real score for variable $X$ was 10155 which meant that the Kyai's role was moderately important.

\section{CONCLUSION}

The role of Kyai in the election of village head at Larangan Luar village in 2019 (variable $\mathrm{X}$ ) that had been divided into two sub-variables (indicators), namely:

- Based on the analysis of sub-variable (indicator) X1, the Kyai's role in in the election of village head at Larangan Luar village in 2019 could be seen in term of exemplary behavior, attitudes and thinking. It was found that the Kyai's role was very important;

- Based on the analysis of sub-variable (indicator) X2, the Kyai's role in in the election of village head at Larangan Luar village in 2019 could be seen in term of effort to persuade other people. It was found that the Kyai's role was moderately important;

- Based on the analysis of variable X (it consists of sub-variable X1 and sub-variable X2), the Kyai's role in the election of village head at Larangan Luar village in 2019 was moderately important. 


\section{REFERENCES}

1. Sartono Kartodirjo, 1990, Kepemimpinan dalam Dimensi Sosial, Jakarta LP3ES.

2. Sokamto, 1999. Kepeimimpinan Kyai dalam Pesantren.Jakarta: LP3ES.

3. Suprayogo,Imam, 2007, Kyai dan Politik. Malang: UIN Malang Press.

4. Suzanne Keller, 1995, Penguasa dan Kelompok Elite. Jakarta: PT Raja Grafisindo Persada.

5. Jurnal Sosiologi Masyarakat, Vol.17, No.1, Januari 2012:23-48.

6. Jurnal Karsa, Vol.XI, No1, April 2007.

7. Jurnal Karsa, Vol. XIII, No.2, Oktober 2007.

8. Jurnal Karsa, Vol. XV, No 1, April 2009. 